\title{
Gentamicin Induces Renal Morphopathology in Wistar Rats
}

\author{
Gentamicina Induce Morfopatología Renal en Ratas Wistar
}

"Vanessa Barboza de Souza; "Rodrigo Fagundes L. de Oliveira; "Hévio Freitas de Lucena; **Aurigena A. A. Ferreira; ** Gerlane Coelho Bernardo Guerra; "Maria de Lourdes Freitas; ${ }^{* * *}$ Karla Cristiane de Souza Queiroz \& ${ }^{* * * *}$ Raimundo F. de Araújo Júnior

DE SOUZA, V. B.; OLIVEIRA, R. F.; LUCENA, H. F.; FERREIRA, A. A. A.; GUERRA, G. C. B.; FREITAS, M. L.; QUEIROZ, K. C. S. \& DE ARAÚJO JÚNIOR, R. F. Gentamicin induces renal morphopathology in Wistar rats. Int. J. Morphol., 27(1):59-63, 2009.

SUMMARY: Due to its prominent role in major excretory pathways, the kidney is particularly sensitive especially to toxicity for antimicrobials drugs. Storage of these drugs in the renal cortex, their effect on renal cells, have consequences on the renal function, and then reabsorbed by renal tubules induce nephrotixicity. Our objective was to show the renal morphopatological alterations induced by gentamicin through the histochemical methods of routine periodic acid de Schiff (PAS) staining and imunohistochemical staining for the expression of the protein P53, which is considered as a marker for cellular apoptosis. This allows the early detection of tubular lesions. The renal morphopathologic findings were cell apoptosis, basal membrane interruption, mesangial proliferation cells, decreased Bowman's space. This result clearly shows that gentamicin administration induces renal morphopatological alterations.

KEY WORDS: Nephrotoxicity; Aminoglycosides; Expression of the P53 protein; Renal morphopatological alterations.

\section{INTRODUCTION}

Since their introduction into therapeutic practice in the 1940's, aminoglycoside antibiotics such as gentamicin and amikacin are commonly used for the treatment of severe Gram-negative bacterial infections (Chambers, 2003).

Aminoglycosides are natural or semi-synthetic antibiotics with a heterocyclic structure formed by two or more aminosugars linked by glycoside bonds to an aminocyclitol ring. Perhaps the most widely used drug in this category is gentamicin. Apart from their beneficial effects, aminoglycosides induce nephrotoxicity in 10-20\% of therapeutic cases. Aminoglycoside-induced nephrotoxicity is characterized by tubular necrosis; basal membrane disruption; mesangial cell contraction; proliferation and apoptosis, indicated by decreases in glomerular filtration and alteration in intraglomerular dynamics (Martínez-Salgado et al., 2007).

Histopathological findings showed that administration of aminoglycosides caused apoptosis, intracellular edema, basal membrane interruption, glomerulus narrowing of the Bowman's capsule and acute tubule necrosis (Souza et al., 2008).

The protein P53 is a nuclear phosphoprotein that regulates the transcription of DNA, cellular proliferation and cellular apoptosis. If the mutations accumulation results in modified proteins, this can be detected by the immunohistochemistry (Barra, 2006).

Notably, recent works suggests a role for P53 protein in tubular cell apoptosis. However, the mechanism of P53 activation remains unclear. Utilization of the P53 protein as a marker of renal damage, could become an advance in the methods of analysis and more important, reveal renal damage caused by aminoglycosides (Jiang et al., 2007). In this work, we studied histological kidney alterations due to chronic treatment with gentamicin, by means of (PASperiodic acid Schiff) staining and P53 protein immunoexpression.

\footnotetext{
Students Department of Morphology, Federal University of Rio Grande do Norte, Natal/RN,, Brazil.

** Professor of Department of Pharmacology, Federal University of Rio Grande do Norte, Natal/RN, Brazil.

**** Research of Amsterdan University.

***** Professor of Department of Morphology, Federal University of Rio Grande do Norte, Natal/RN, Brazil.
} 


\section{MATERIAL AND METHOD}

Male Wistar rats 8-12 weeks, weighing 200-250g, were placed in a temperature $\left(23 \pm 2^{\circ} \mathrm{C}\right)$ controlled room in which a 12:12h light: dark cycle was maintained. Twentyfive rats were randomly assigned to 5 experimental groups of five animals that each received gentamicin $0,08 \mathrm{ml}$ of treatment intraperitoneally. The control group was treated with saline for 28 days. Groups I, II, III and IV were injected intaperitoneally with gentamicin for 7, 14, 21 and 28 days respectively. After treatment, the animals in all groups were sacrificed and the kidneys were quicky removed, decapsulated and divided longitudinally into two equally sized pieces. One piece was placed in formaldehyde solution to be embedded in parafine. $5 \mu \mathrm{m}$-thick sections were cut for histopathologic examination, by light microscopy.

\section{Histological evaluation}

Histochemistry. The renal tissues slides were stained with periodic acid Schiff (PAS) reagent and examined light microscopy. The PAS reaction stains carbohydrates and carbohydrates-rich macromolecules. It is used to visualize the basal membrane that underlies epithelia. Three coded slides from each kidney were examined in a blinded manner.

Immunohistochemistry. With some modifications, the used technique followed the recommendations of Taylor $e t$ al. (1994) and Iwakura et al. (2000). Incubation with the primary antibody P53 the 1/25 per 60 minutes with BSA. After this, the sections were incubated with the secondary antibody LSAB (complex DAKO). The slide were counterstained with hematoxilin of Mayer for 10 minutes.

Qualitative and quantitative evaluation of morphology. The morphology of the PAS stained structures of the renal glomerule was evaluated by the number of mesangial cells; the state of the basal membrane of the glomerulari capilaris; the mesangial extracellular matrix; continuity of basal membrane of renal glomerule and parietal cells. The proximal and distal tubules and were evaluated by means of morphology of revestiment cells (apoptosis and necrosis).

The kidney sample sections were analyzed with a microscope (with camera) connected to a microcomputer. As we verified in previous works, in experimental work of Iwakura $e t$ al. analysis of the slides was done in 4 fields by quantifying the number of cells positive for the protein P53 staining in 100 cells for field, at a 40x magnification.

Statistical analysis. The renal morphopathological and the morphologic analysis for P53 alterations were analysed statistically with the Kruskal-Wallis Test and Dunn's Multiple Comparisons Test (5\% statistical significance).

\section{RESULTS}

The results of renal morphopathological alterations found through histochemical method PAS to the diferences groups treated with gentamicin are in Fig. 1.

Histological examination of the kidneys from animals in the control group revealed, as expected, entirely normal histological features, illustrated in Figs. 2A and 2D. However, there was tubular necrosis in kidneys from animals in the gentamicin treated group, particularly the groups 3 and 4 , illustred in Figs. 2B, 2C and 2E, respectively. There was a increased number of mesangial cells; the lumen of the tubules were filled with degenerate and desquamated epithelial cells, apoptotic cells. Furthermore interruptions in the basal membrane are present.

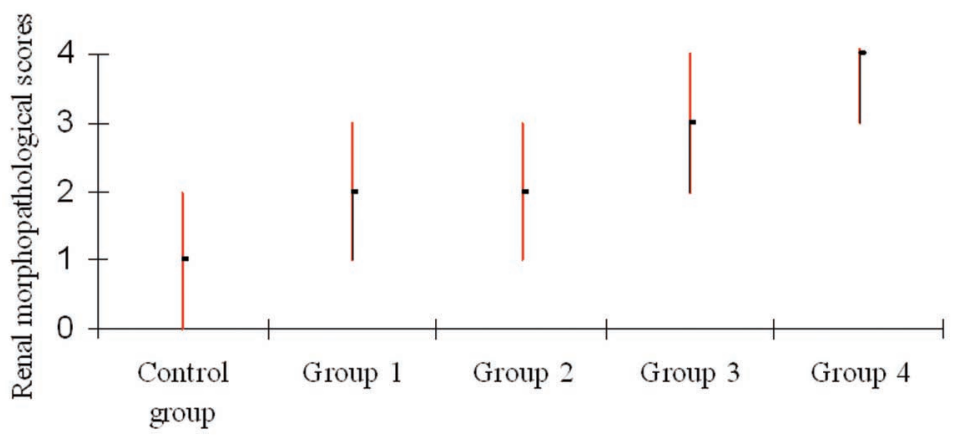

Fig. 1. Morphologics comparisons between control group and all treated gentamicin groups (PAS). Group 01 vs. Control group ( $>00.05)$. Group 02 vs. Control group $(\mathrm{p}<0.05)$. Group 03 vs. Control group $(\mathrm{p}<0.001)$. Group 04 vs. Control group $(\mathrm{p}<0.001)$. Group 01 vs. Group 02 ( $\mathrm{p}>0.05)$. Group 01 vs. Group $03(\mathrm{p}<0.001)$. Group 01 vs. Group $04(\mathrm{p}<0.001)$. Group 02 vs. Group 03 ( $>>0.05)$. Group 02 vs. Group 04 ( $p<0.001)$. Group 03 vs. Group 04 ( $p>0.05)$. 
Table I. Scores of renal histological alterations in Wistar rats.

\begin{tabular}{|c|c|c|c|c|c|}
\hline Scores & $\begin{array}{l}\text { Histological } \\
\text { characteristics }\end{array}$ & 1 (unaltered) & 2 (slight) & 3 (moderate) & 4 (severe) \\
\hline A & $\begin{array}{l}\text { Alterations of parietal } \\
\text { cells. Bowman's } \\
\text { capsule. }\end{array}$ & $\begin{array}{l}\text { Unaltered } \\
\text { characteristics. }\end{array}$ & $\begin{array}{l}\text { Cells parietal } \\
\text { alterations } \\
\text { morphological. }\end{array}$ & $\begin{array}{l}\text { Decreased Bowman's } \\
\text { capsule. }\end{array}$ & $\begin{array}{l}\text { Cells altered } \\
\text { morphology. decreased } \\
\text { Bowman's Capsule. }\end{array}$ \\
\hline B & $\begin{array}{l}\text { Basal membrane } \\
\text { (PAS). }\end{array}$ & $\begin{array}{l}\text { Unaltered } \\
\text { characteristics. }\end{array}$ & $\begin{array}{l}\text { Discret interruption } \\
\text { basal membrane. }\end{array}$ & $\begin{array}{l}\text { Interruption basal } \\
\text { membrane. }\end{array}$ & $\begin{array}{l}\text { Intense interruption } \\
\text { basal membrane. }\end{array}$ \\
\hline $\mathrm{C}$ & $\begin{array}{l}\text { Mesangial cells. } \\
\text { cellular apoptosis(PAS } \\
\text { \& P53) }\end{array}$ & $\begin{array}{l}\text { Unaltered } \\
\text { characteristics. }\end{array}$ & $\begin{array}{l}\text { Discret increased of } \\
\text { mesangial cells. }\end{array}$ & $\begin{array}{l}\text { Moderate increased of } \\
\text { mesangial cells. } \\
\text { Apoptosis. }\end{array}$ & $\begin{array}{l}\text { Increased mesangial } \\
\text { cells. Apoptosis. }\end{array}$ \\
\hline $\mathrm{D}$ & $\begin{array}{l}\text { Tubule proximal cells; } \\
\text { cellular apoptosis. } \\
\text { (PAS \& P53) }\end{array}$ & $\begin{array}{l}\text { Unaltered } \\
\text { characteristics. }\end{array}$ & $\begin{array}{l}\text { Integral brush-border } \\
\text { membrane; level } \\
\text { desquamationcells. }\end{array}$ & $\begin{array}{l}\text { Interruption brush-border } \\
\text { membrane. Apoptosis } \\
\text { and tubular necrosis. }\end{array}$ & $\begin{array}{l}\text { Complete interruption } \\
\text { basal membrane. } \\
\text { Apoptosis/ necrosis. }\end{array}$ \\
\hline
\end{tabular}

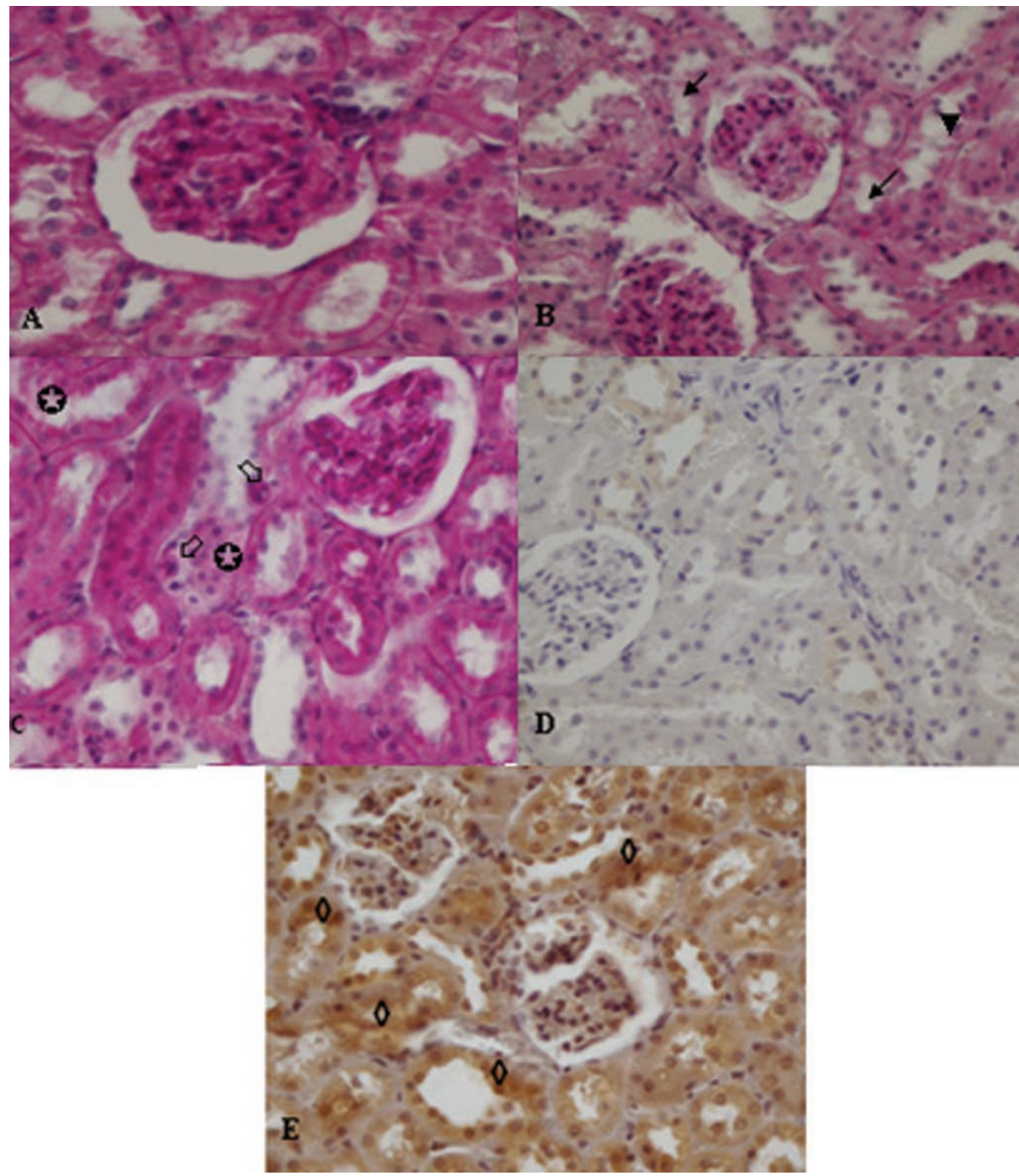

Fig. 2. Morphopathological evaluation of kidney samples. A. Glomeruli and tubules have a normal appearence in samples from the control group. Periodic acid Schiff (PAS) stain. B. Basal membrane interruption ( $Æ$ ) and tubular obstruction $(\mathrm{t})$ is observed in samples from the group 3 treated with gentamicin. PAS. C. Tubular marked necrosis $(\Rightarrow)$ and tubular obstruction $(\oplus)$ is observed in group 4. PAS. D. Renal glomeruli and tubules of control group have normal features. P53 protein marker. E. Appearance in samples from the group 4 altered with severe cellular apoptosis (à). P53 protein marker. 


\section{DISCUSSION}

Aminoglysosides antibiotics induce a dosedependent nefrotoxicity in $10-25 \%$ of therapeutic cases, despite rigorous monitoring of serum drug concentration and adequate fluid volume control. Aminoglysosides-induced nephrotoxicity is typically characterized by tubular necrosis (Rodríguez-Barbero et al., 1997). In this study observed in group with 03 and 04 weeks of treatment significanty $(\mathrm{p}<0.001)$. In addition to causing changes in filtration, gentamicin has been shown to induce proximal tubular injury, with the damage ranging from alterations in tubular reabsorption to necrosis of proximal tubule cells (Polat et al., 2006; Gibey et al., 1981).

Mensangial cells have functions in synthesis and assembly of the mensaglial matrix, which in turn regulates the viscoelastic and hydraulic properties of the mensagium. In different studies it was was shown that gentamicin stimulates mensangial cells contraction and proliferation on primary cultures of mensangial cells (Rodríguez-Barbero $e t$ al., 1995; Martínez-Salgado et al., 1997). In the present study, contraction and proliferation of mesangial cells was observed and was significant in the group of animals with 03 weeks gentamicin treatment $(\mathrm{p}<0.000)$. Another in vitro study showed the contractive and proliferative effects of gentamicin on mesangial cells, what also was observed invivo (MartínezSalgado et al., 2004).

Apoptosis is an essential process in the development and tissue homeostasis of most multicellular organisms. There are experimental data suggesting that the neprotoxicity may be closely associated with activation of proapoptotic proteins (Han et al., 2006). Further, among the various subcellular organelles potentially involved in apoptosis, both lysosomes and mitochondria have been shown to send death signals through the activation of specific stress sensors. It was found that lysosomes membrane rupture and release of acid hydrolases contribute to apoptosis and necrosis of proximal tubular cells, this was identified in pathological situations (Servais et al., 2005).

Ours morphopathological findings, including: a diminished Bowman's capsule, apoptosis and cellular necrosis, mesangial proliferation, tubular obstruction, and basal membrane interruption in groups treated with gentamicin, in comparison with control group, show that gentamicin induces renal morphopathological alterations.

DE SOUZA, V. B.; OLIVEIRA, R. F.; LUCENA, H. F.; FERREIRA, A. A. A.; GUERRA, G. C. B.; FREITAS, M. L.; QUEIROZ, K. C. S. \& DE ARAÚJO JÚNIOR, R. F. Gentamicina induce morfopatología renal en ratas Wistar. Int. J. Morphol., 27(1):59-63, 2009.

RESUMEN: Debido a su importante rol en la función de excreción mayor, el riñón es especialmente propenso a la toxicidad por los antibióticos bactericidas. La acumulación de los antibióticos aminoglicosidos en la corteza renal tiene como consecuencia efectos en las células renales y en la función renal y cuando son reabsorbidos por los túbulos renales, pueden conducir a toxicidad renal. Nuestro objetivo fue mostrar alteraciones morfopatológicas renales causadas por la administración de gentamicina, a través de métodos histoquímicos de rutina con ácido periódico de Schiff (PAS) y tinción inmunohistoquímica para la expresión de la proteína P53, la cual es considerada como un marcador para la apoptosis celular, permitiendo la detección precoz de lesiones tubulares. Los resultados morfopatológicos renales fueron apoptosis celular, interrupción de la membrana basal, proliferación de células mesangiales y disminución del espacio de Bowman. Los resultados mostraron claramente que la administración de gentamicina induce alteraciones morfopatológicas renales. renales.

PALABRAS CLAVE: Nefrotoxicidad; Aminoglycosides; Expresión de la proteína P53; Alteraciones morfopatológicas

\section{REFERENCES}

Barra, M. B. O uso da imunohistoquímica no diagnóstico: indicações e limitações. Rev. AMRIGS, 50(2):173-84, 2006.

Chambers, H. F. As bases farmacológicas da terapêutica. $10^{\text {a }}$ Ed. Rio de Janeiro, McGraw-Hill, 2003. pp.913-24.

Gibey, R.; Dupond, J. L.; Alber, D.; Leconte des Floris, R. \& Henry, J. C. Predictive value of urinary N-acetyl-beta-
D-glucosaminidase (NAG), alanine-aminopeptidase (AAP) and beta-2-microglobulin (beta 2M) in evaluating nephrotoxicity of gentamicin. Clin. Chim. Acta., $116(1): 25-34,1981$.

Han, S. Y.; Chang, E. J.; Choi, H. J.; Kwak, C. S.; Park, S. B.; Kim, H. C. \& Mun, K. C. Apoptosis by cyclosporine in mesangial cells. Transplant. Proc., 38(7):2244-6, 2006. 
Iwakura, R.; Martins, A. C. P.; Tucci Junior, S.; Pastorello, M. T.; Suaid, H. J.; Cologna, A. J. \& Carneiro, A. D. C. Proteína P53 em nefroblastomas. Acta Cir. Bras., 15(2):50-2, 2000.

Jian, M.; Wei, Q.; Pabla, N.; Dong, G.; Wang, C. Y.; Yang, T.; Smith, S. B. \& Dong, Z. Effects of hydroxyl radical scavenging on cisplatin-induced P53 activation, tubular cell apoptosis and nephrotoxicity. Biochem. Pharmacol., 73(9):1499-1510, 2007.

Martínez-Salgado, C.; Eleno, N.; Morales, A.; PérezBarriocanal, F.; Arévalo, M. \& López-Novoa, J. M. Gentamicin treatment induces simultaneous mesangial proliferation and apoptosis in rats. Kidney Int., 65:216171, 2004.

Martínez-Salgado, C.; Henández-López, F. J. \& NovoaLópez, J. M. Glomerular nephrotoxicity of aminoglycosides. Toxicol. Appl. Pharmacol., 223(1):8698, 2007.

Martínez-Salgado, C.; Rodríguez-Barbero, A.; RodríguezPuyol, D.; Pérez de Lema, G. \& López-Novoa, J. M. Involvement of phospholipase A2 in gentamicin-induced rat mesangial-induced rat mesangial cell activation. Am J Physiol., 273(1):60-6, 1997.

Polat, A.; Parlakpinar, H.; Tasdemir, S.; Colak, C.; Vardi, N.; Ucar, M.; Emre, M. H. \& Acet, A. Protective role of aminoguanidine on gentamicin-induced acute renal failure in rats. Acta Histochem., 108(5):365-71, 2006.

Rodriguez-Barbero, A.; López-Novoa, J. M. \& Arévalo, M. Involvement of platelet activating factor in gentamicin induced nephrotoxicity in rats. Exp. Nephrol., 5(1):4754, 1997.

Rodriguez-Barbero, A.; Rodriguez-Lopez, A. M.; GonzalezSarmiento, R.; López-Novoa, J. M. Gentamicin activates rat mesangial cells. A role for PAF. Kidney Int., 47(5):1346-53, 1995.

Servais, H.; Van Der Smissen, P.; Thirion, G.; Van der Essen, G.; Van Bambeke, F.; Tulkens, P. M. \& MingeotLeclercq, M. P. Gentamicin-induced apoptosis in LLCPK1 cells: involvement of lysosomes and mitochondria. Toxicol. Appl. Pharmacol., 206(3):321-33, 2005.

Souza, V. B.; Oliveira, R. F. L.; Ferreira, A. A. A. \& Araújo Júnior, R. F. Alterações renais por aminoglicosídeos. Arq Med., 22(4-5):131-5, 2008.
Taylor, C. R.; Shi, S. R.; Chiwun, B.; Young, L.; Imam, A. S. \& Cote, R. J. Strategies for improveing the immunohistochemical staining of various intranuclear prognostic markers in formalin-parafin sections: androgen receptor, estrogen receptor, progesterone receptor, P53 protein, proliferating cell nuclear antigen, and $\mathrm{Ki}-67$ antigen revealed by antigen retrieval techniques. Hum. Pathol., 25(3):263-70, 1994.

Correspondence to:

Aurigena A. A. Ferreira

Professor of Department of Pharmacology

Federal University of Rio Grande do Norte

Natal/RN

BRAZIL

Email: aurigena@ufrnet.br

Received: 06-10-2008

Accepted: 18-11-2008 
